\title{
Support for innovative on-street parking policies: empirical evidence from an urban neighborhood.
}

\begin{abstract}
Municipalities and planners often hesitate to implement restrictive parking policies because residents regularly oppose any changes to on-street parking space. Residential parking is one key factor of parking management because its location and availability influence a household's car ownership and use. Moreover, as more residents regularly use other means of transportation that need space and infrastructure in the urban realm, and as parking takes up a vast amount of land, municipalities are considering the reuse of on-street parking space for other purposes. As public acceptability is a precondition for the successful implementation of a proposed policy, our empirical analysis investigates to what extent residents support restrictive and demand-oriented on-street parking policies in the dense, highly urbanized neighborhood of Frankfurt-Bornheim, Germany $(\mathrm{N}=1027)$. Surprisingly, despite some variations, the majority of the residents in our survey are in favor of the policy options suggested. Support for the demand-oriented policies (extension of bicycle infrastructure, improved sharing supply and mobility hubs, neighborhood garages, and improved public transit supply) is higher than the acceptance of the restrictive policies, and of policies that are a combination of restrictive and demandoriented policies. However, surprisingly, a majority is still in favor of many of these (extension of parking fees and parking restrictions, and reuse of parking space for better livability). Furthermore, we classify residents who live in a household with private cars into the stage model of self-regulated behavior change to analyze their intention towards a reduction in private car use. Results from linear regression analyses indicate that residents who have intentions to change their behavior towards car use reduction assess the policy options more similarly to car-free households and regular bike users, and not like the other car-owning households. The findings suggest that while the residents support financialrelated policies the least, they are more receptive towards parking policies than policy makers and planners assume if the reuse of parking lots creates space for other users or if it increases the quality of life, for instance, by adding bike lanes, wider sidewalks or greenery. Hence, a combination of restrictive and demand-oriented on-street parking policies results in high acceptance among residents, and the communication from municipalities regarding the implementation of the different policies needs to vary depending on the kind of household.
\end{abstract}

Keywords: parking space; parking policy; parking restrictions; behavior change; stage model; urban neighborhood

\section{Introduction}

Usually, when a municipality plans to reuse on-street parking space for other purposes like bicycle parking facilities or resting areas, it is confronted with resistance from residents towards any changes in urban parking. This impression is consistent with research regarding restrictive policies, suggesting that public acceptability, not only from the residents but also from other stakeholders in residential neighborhoods like local businesses, is a precondition for successful implementation (Schaller, 2010; Grisolía et al., 2015; Chang, 2014). On the one hand, several studies discovered low acceptance among residents of restrictive or financial-related policies such as road pricing (Kim et al., 2013; Schade and Schlag, 2003), while on the other hand, residents seem to support demand-oriented policies. For example, Steg (2003) discovered that while pricing instruments are the least accepted, demand-oriented policies that improve the quality of public transport and bicycle facilities have the highest acceptance. Public acceptability of the implementation of parking management in municipalities and its arrangement is important because the residential parking availability and parking location are connected to households' car ownership rate and car use (Antonson et al., 2017; Christiansen et al., 2017; Weinberger et al., 2009). Moreover, the parking availability also influences the frequency of public transit use 
(Johansson et al., 2019). Therefore, parking management is a key factor promoting the use of alternative means of transportation. Furthermore, though urban space is a scarce resource, parking takes up a vast amount of land and uses public spaces that could have different functions (Gehl, 2010; Mingardo et al., 2015; Newman and Kenworthy, 2015; Notz, 2017). In addition, recent developments like the increasing provision and use of carsharing ${ }^{1}$ may further encourage reduced private car ownership and car use (Nehrke and Loose, 2018; Schreier et al., 2015). If people owned fewer private cars and used stationbased carsharing services instead, the amount of parking space needed would decrease and cities could reutilize the space for other purposes.

Still, to the best of our knowledge, most studies regarding restrictive policies focus on road pricing and there has been no extensive research about residents' acceptance around parking-related restrictive and demand-oriented policies. There are various classifications for the different types of policies (e.g. Loukopoulos, 2007; Banister, 2005; Kaufmann-Hayoz, 2001) and we differentiate between two types: restrictive and demand-oriented policies. The former include financial-related instruments, and aim at impeding private car use. The latter increase the supply of alternatives to the private car. Thus, the parking policies aim to work in two ways: to influence and change the mobility of residents towards a more sustainable mobility, and to reallocate the public space to increase the quality of life in the neighborhood. Moreover, so far, there has been no analysis as to whether the intention towards a change in car use affects the support of such policies. Since the successful implementation of the parking policies includes the behavior change of residents, it is of interest to determine their intention towards reduced private car use. With the stage model of self-regulated behavior change (SSBC), we apply one such approach to measure the process to reduce car use voluntarily (Bamberg et al., 2011).

Therefore, the objectives of this paper are twofold: first, to determine to what extent residents accept restrictive and demand-oriented on-street parking policies in a dense urban neighborhood. We include one restrictive parking policy option, (1) the extension of parking fees and parking restrictions, and one combined option, (2) the reuse of parking space for better livability in our empirical analysis. Furthermore, four parking policy options are demand-oriented: (3) extension of bicycle infrastructure, (4) improved supply of sharing services and mobility hubs, (5) neighborhood garages, and (6) improved public transit supply. The second aim of this paper is to analyze whether various characteristics of the residents affect the support for the parking policies suggested: the ownership of a car or a bicycle, carsharing membership, the regular use of different means of transportation, the availability of residential car parking, and an individual's intention towards reducing car use measured with the SSBC. Thereupon, we conducted a household survey in the centrally located neighborhood of Bornheim in the city of Frankfurt am Main.

The paper is structured as follows. In the next section, we summarize the state of the art regarding research on car parking in urban neighborhoods, the acceptance of parking policy options, and the stage model of self-regulated behavior change (SSBC). We introduce the case study, and methods used to conduct the research in section 3 . In section 4 , we present the results regarding the acceptance of parking policies, which we discuss in section 5. In the last section, we summarize the main findings.

\section{Components of parking management and its acceptance}

\subsection{Parking in urban neighborhoods}

The average private car is used for around one hour a day, and most of this time it is parked at the residence (Marsden, 2014; Mattioli et al., 2019; Shoup, 2005). As the residential parking location and

${ }^{1}$ Otherwise called car clubs. 
availability is connected to a household's car ownership and car use (e.g. Johansson et al., 2019; Christiansen et al., 2017; Guo, 2013; Weinberger et al., 2009), parking is a key factor of urban transportation demand management. Though almost every city or town has parking requirements for housing and commercial developments, the majority of municipalities use minimum requirements, however, and maximum requirements often only apply in city centers with good access to public transit (Antonson et al., 2017; Christiansen et al., 2017). Moreover, for both on-street and off-street parking, on average, private cars require four parking spaces of twelve square meters each (e.g. at the residence, the workplace, the supermarket, the stadium) (Marsden, 2014; Shoup, 2005). For the US, Chester et al. (2010) estimate there are alone between 35 million and one billion on-street parking spaces available for around 250 million vehicles. Thus, parking takes up a vast amount of space that is not usable for other users of public space. Floating car traffic and parking still occupy most urban streets, though the number of people who mainly use other means of transportation or carsharing is steadily increasing or remains high. For example, in Germany, forty percent of households in the major cities like Hamburg and Munich live without private cars (Infas and DLR, 2019). Therefore, parking management is a significant element for managing the use of urban space, the urban transport system, and individuals' mobility behavior patterns. Parking management consists of a toolbox of different policies and programs like maximum parking requirements and a varying pricing scheme. Yet, parking management not only focuses on vehicle parking, but also incorporates, for instance, the improvement of pedestrian and bicycling infrastructure, public transit accessibility, and general land use patterns (Litman, 2016; Mingardo et al., 2015; Rye and Koglin, 2014). Thus, different kinds of parking-related policy options that complicate private car use or incentivize the use of other means of transportation are an important tool for municipalities to manage urban mobility (Buehler et al., 2016; Kirschner and Lanzendorf, 2019).

\subsection{Measuring the acceptance of policy options for parking management}

Parking management is an essential tool for municipalities to shape urban mobility. While demandoriented policies aim at influencing individuals' decision-making and increasing the attractiveness of alternatives to the private car, restrictive measures intend to limit or sanction private car use (Bamberg et al., 2011). However, these two groups of policies indicate different levels of effectiveness and acceptance from residents (Harms and Probst, 2008; Steg, 2003). The literature suggests that voluntary policies have higher support than restrictive ones, especially financial instruments like road pricing, congestion charging, and environmental taxation (e.g. Kim et al., 2013; Schade and Schlag, 2003; Jakobsson et al., 2000). For example, Steg (2003) observes that effective policies have low support from residents (e.g. economic policies like road tolls or parking fees), while policies with high support show unclear effects (e.g. better bicycle facilities). Yet, other authors measured the process of voluntary caruse reduction, which can lead to an increased effectiveness of demand-oriented policies, and can be utilized in travel programs, such as marketing campaigns for new residents (Bamberg et al., 2011; Bamberg et al., 2008).

Furthermore, the acceptance of policies depends on their perceived effectiveness, the policies' longterm goals, and the role of the government (Grisolía et al., 2015; Schmöcker et al., 2012; Schade and Schlag, 2000). For instance, Kim et al. (2013) discovered that general trust in the government is significant for the acceptance of road pricing and environmental taxation among UK and US students. Moreover, several studies illustrate that the success of an implementation is dependent on personal factors, like the perceived fairness and infringement of freedom, and the expected personal outcome. This means the way car drivers view the effect of the proposal on them personally (Kim et al., 2013; Schmöcker et al., 2012; Schaller, 2010; Schade and Schlag, 2003; Jakobsson et al., 2000). In addition, Schaller (2010) points out the power of small interest groups to block proposed implementations, as was the case for congestion pricing in New York City, and the important role of municipalities to communicate the benefits of the new policies for all users effectively. 
Finally, Marsden (2014) argues that municipalities need to reinforce demand-restraining parking policies by reallocating road space and different land-use planning as part of parking policies. Otherwise, these policies will be unpopular and ineffective. Furthermore, Steg (2003) concludes that the combination of instruments and whether they are part of a city's policy goals might be most effective. Bamberg et al. (2011) point out the interdependence of hard and soft measures. To incorporate the discussion in the literature and make use of the results from previous work, we used a combination of both restrictive and demand-oriented instruments for the parking survey.

\subsection{Behavior change as a process of different stages}

To measure and improve our understanding of the effectiveness of parking policies, we employ the stage model of self-regulated behavior change (SSBC) to assess the intention towards a reduction in private car use (Bamberg, 2013; Bamberg et al., 2011). The SSBC is based on the transtheoretical model (DiClemente and Prochaska, 1982; Prochaska and DiClemente, 1983). The SSBC understands behavior change as a process and identifies a sequence of four different stages of self-regulated behavior change: predecisional, preactional, actional, and postactional (figure 1). However, as it is a model, the occurrence of the stages is not necessarily a linear process, and individuals do not automatically get from one stage to the next. Instead, one can skip a stage, stay in a stage for a longer time or fall back into an earlier stage. Intentions between the phases indicate the transition from one phase to the next: goal intention, behavioral intention, and implementation intention. In the first stage (predecisional), an individual is satisfied with one's current frequent car use, and does not see reasons to think about car use reduction. Here, an individual needs to become aware of one's behavior to be able to evaluate it and form a goal intention towards less car use. The second stage (preactional) is characterized by investigating which probable new actions fit best into one's personal situation, i.e. how to compensate reduced car use. The formulation of a new behavior, for instance, to use the subway to go to work instead of the car, marks the behavioral intention. The third stage (actional) includes the preparation and testing of the new behavior, which an individual chose in the previous stage, e.g. using the subway the next morning to get to work. Therefore, the individual needs to develop a concrete plan of action as an implementation intention. Finally, in the fourth stage (postactional), the habitualization of the new behavior is necessary to prevent falling back into old behavior.

As we use the model to ascertain a behavior change towards reduced car use, individuals in stages one to four live in households with private cars. Their car use differs from frequent use in stage one to lower use in stage four. We classify individuals from car-free households into the postactional stage as well because we assume their car use is even lower as they do not own private cars. However, their behavior is not necessarily static either and they may purchase a private car (again). In addition, they have not necessarily been through the stages of the behavior change because they may have never owned a car. Moreover, the motive to live without private cars can be either intentional or it may be forced due to financial or other impairment reasons.

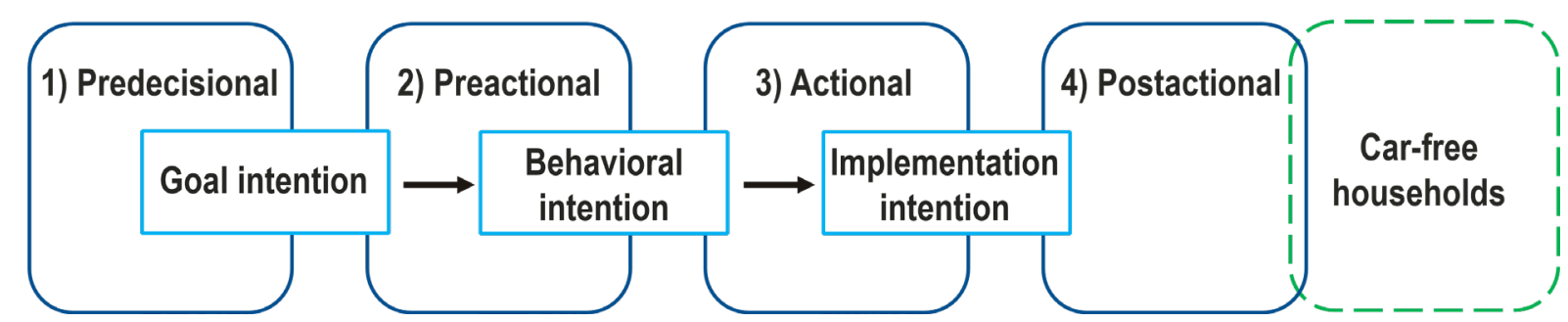

Figure 1: Stage model of self-regulated behavior change towards reduced private car use. (Own diagram, based on Bamberg, 2013.) 


\section{Methods}

\subsection{Case study of Frankfurt-Bornheim}

In February and March 2018, we conducted a household survey in the neighborhood of Bornheim, which is centrally located in the city of Frankfurt am Main. Approximately 30,000 inhabitants live in Bornheim, and it has one of the highest population densities in Frankfurt (City of Frankfurt, 2019). In Germany, parking policies are regulated at municipality level, and the parking regulations in Frankfurt for new developments and reconstructions mainly work as minimum requirements. Currently, in most of the neighborhood, on-street parking is free of charge and without time limits. Yet, there is a residential parking zone in the southern part of the neighborhood. As in the rest of the city, a residential parking permit for a zone costs 25 euros per year. In addition, as part of the parking zone, a Frankfurt-wide complementary fifty percent rule applies. This means that usually one half of the zones with residential parking permits still needs to be freely available for anyone at least fifty percent of the time. So one side of the street is reserved for residents with parking permits, and on the other side parking is allowed at any time and is free of charge.

\subsection{Survey}

The survey was part of a larger research project about persistence and dynamics in urban neighborhoods. It is funded by the German ministry of education and research, and as a transdisciplinary project, it is a collaboration between universities, municipalities, and transport planning companies. It was a crosssectional survey and we used random route sampling combined with the last birthday method (Diekmann, 2017; Fuller, 2009; Binson et al., 2000). For random route sampling each interviewer ${ }^{2}$ begins at a specific start cluster and follows a route that we determined beforehand. The interviewers put the surveys in every second mailbox of every second building that they passed by along their routes. First, we prepared a list with all streets in the neighborhood from which we filtered streets without residential buildings (e.g. schools), and we divided long streets so that short ones are not overrepresented. Second, we defined the start cluster of each interviewer. For that, we randomly selected a street name for each interviewer and we calculated the house numbers for the start clusters from each interviewers' birth date (year/day, e.g. 95/15=6). The route for each interviewer followed a scheme ${ }^{3}$ that we determined beforehand (Groth, 2016; Kromrey, 2002). We administered the pretest in the last week of February 2018 and we distributed the main survey in the first two weeks of March 2018. Overall, we distributed 3,000 surveys, which the participants sent back by regular mail. We also provided the option to participate in the survey using a tablet and the cover letter of the survey explained both options. We used reminders to increase the return rate, and, therefore, each interviewer had to walk along his/her route again after the distribution of the survey and had to try to reach each household along the route. If no one was reached, the interviewers had to leave a reminder card in the mailbox. If they reached someone, they had to ask whether the household had already participated and whether they were interested in using the tablet option. In summary, we made sure that all households that received a survey were contacted again at least once and at least through one media (card or personal communication). The survey consisted of six blocks that covered the areas life in Bornheim, availability of means of transportation, frequency of use of means of transportation, mobility in Bornheim, policy options in Bornheim, and socio-demographics. It took approximately twenty minutes to complete it. The overall return rate was thirty-four percent $(\mathrm{N}=1,027)$ and less than two percent chose the tablet offer, while the

\footnotetext{
${ }^{2}$ The interviewers were undergraduate students from a seminar about quantitative methods.

${ }^{3}$ When you walk on the right side of the street, turn left at the next intersection, and continue on the left side of the street; when you walk on the left side of a street, turn right at the next intersection, and continue on the right side of the street.
} 
majority filled out the paper version (Kirschner, 2019). We substituted missing values by means of multiple imputation (Spieß, 2010).

In our sample, female participants, older people, and large households are overrepresented compared to data available from the city administration (table 1). Sixty percent of the participants are female, and the mean age is fifty years. Half of the participants live alone in their household, and fifty-five percent of the participants are university graduates. Nearly forty percent do not own a private car, and almost half of the participants regularly drive a private car. More than seventy percent of participants own a bicycle, and almost fifty percent use a bicycle at least once per week. In addition, two thirds use public transit on a regular basis. Almost nine out of ten participants regularly walk to destinations. Furthermore, nearly twenty percent are registered at a carsharing company (both stationary and free-floating). Around forty percent of the residents from households with private cars usually park their cars on rented off-street parking lots, which may be either above or underground. More than fifty percent of residents from households with cars usually park their cars on-street in the public space, where they can leave their cars (almost) free of charge and without a time limit because in most places there is no pricing scheme set up (3.1).

Table 1: Descriptive statistics of variables used for the analysis $(\mathrm{N}=1027)$ in comparison to available city statistics.

\begin{tabular}{|c|c|c|c|c|c|}
\hline \multicolumn{2}{|l|}{ Socio-demographics } & \multicolumn{2}{|c|}{ Sample } & \multirow{2}{*}{$\begin{array}{c}\text { Bornheim } \\
\text { Mean }\end{array}$} & \multirow{2}{*}{$\begin{array}{c}\text { Frankfurt } \\
\text { Mean }\end{array}$} \\
\hline Variable & Description & Mean & SD & & \\
\hline Gender: male $^{*}$ & female (0); male (1) & 0.40 & 0.49 & 0.47 & 0.50 \\
\hline Mean age ${ }^{* 1}$ & Age in years $(18-92)$ & 50.5 & 15.539 & 42.7 & 40.8 \\
\hline University degree & No (0); yes (1) & 0.55 & 0.49 & no data & no data \\
\hline Non-single household ${ }^{*}$ & Single household $(0) ; \geq 2$ people $(1)$ & 0.51 & 0.50 & 0.39 & 0.47 \\
\hline Persons/household ${ }^{*}$ & Number of household members & 1.82 & 1.055 & 1.66 & 1.87 \\
\hline Monthly net household income & Income in Euro & 3,250 & 1.152 & no data & no data \\
\hline \multicolumn{6}{|l|}{ Ownership/carsharing membership } \\
\hline Households without car ownership & no car $(1) ; \geq 1$ car $(0)$ & 0.39 & 0.488 & no data & no data \\
\hline Private bicycle ownership & No (0); yes (1) & 0.72 & 0.448 & no data & no data \\
\hline Private carsharing membership & No (0); yes (1) & 0.18 & 0.382 & no data & no data \\
\hline \multicolumn{6}{|l|}{ Transport modes: Regular ${ }^{2}$ users of ... } \\
\hline$\ldots$ private car as driver & Non- regular use (0); regular use (1) & 0.45 & 0.498 & no data & no data \\
\hline ... public transit & Non- regular use (0); regular use (1) & 0.67 & 0.471 & no data & no data \\
\hline$\ldots$ bicycle & Non- regular use (0); regular use (1) & 0.47 & 0.499 & no data & no data \\
\hline$\ldots$ walking $^{3}$ & At a non-regular level (0); at a regular level (1) & 0.88 & 0.324 & no data & no data \\
\hline \multicolumn{6}{|c|}{ Residential parking (residents from car owning households only, $N=627$ ) } \\
\hline \multirow[t]{2}{*}{ Users of residential on-street parking } & $\begin{array}{l}\text { own parking space and rented off-street parking } \\
(0) \text {; on-street parking and parking permit (1) }\end{array}$ & 0.56 & 0.497 & no data & no data \\
\hline & & \multicolumn{2}{|c|}{$\mathrm{N}=1,027$} & $\mathrm{~N}=30,533$ & $\mathrm{~N}=747,848$ \\
\hline
\end{tabular}




\subsection{Behavior change variables}

We applied the SSBC to households with at least one private car because we wanted to assess their intention towards reducing car use. For that purpose, we asked residents nine different questions. Based on a Guttman scale (Scott and Marshall, 2015), we categorized the individuals into the four stages by three indicator variables: goal intention, behavioral intention, and implementation intention (table 2). To indicate the classification for both the predecisional and preactional stage, we used seven constructs and calculated their mean as the indicator variable for the goal intention. The constructs define the intention from the first to the second stage. For the classification into the actional and postactional stage, we used one indicator variable for each intention.

If a person approved the statements for the variable/s of a stage and dismissed the statements for the variables of the further stages, we classified the person into that stage to which he/she agreed. Hence, if a person did not approve every statement of all indicator variables, we classified this person into the predecisional stage. If a person approved the indicator variables of the preactional stage but not the indicators for the actional and postactional stage, we classified this person into the preactional stage. We classified a person into the actional stage, if this person approved the statement for the actional stage but did not approve the indicator variable of the postactional stage. Finally, if a person approved the statement for the postactional stage, we assigned the person to this stage. Consequently, we based the classification of the individuals on their answers for a stage (actional and postactional stages) and independently of an individual's answer for prior stages (figure 2).

Table 2: Indicators for classifying behavior change stages (based on Bamberg, 2012).

\begin{tabular}{|c|c|c|c|}
\hline Intentions & Construct & Indicator variables in the survey & Five point Likert scale \\
\hline \multirow{7}{*}{$\begin{array}{l}\text { Goal intention } \\
\text { (for preactional } \\
\text { stage) }\end{array}$} & $\begin{array}{l}\text { 1) Valued possibility for } \\
\text { behavior change }\end{array}$ & To reduce my car use in the near future, would be ... & \multirow{2}{*}{$\begin{array}{l}\text { (1) very easy. } \\
\text { (2) easy. } \\
\text { (3) neither easy nor difficult. } \\
\text { (4) difficult. } \\
\text { (5) very difficult. }\end{array}$} \\
\hline & $\begin{array}{l}\text { 2) Valued possibility for } \\
\text { behavior change }\end{array}$ & To give up my car soon, would be ... & \\
\hline & 3) Social norm & $\begin{array}{l}\text { Most people, who are important to me, would like it } \\
\text { if I reduced my car use. }\end{array}$ & \multirow{4}{*}{$\begin{array}{l}\text { (1) Strongly agree } \\
\text { (2) Agree } \\
\text { (3) Neither agree nor disagree } \\
\text { (4) Disagree } \\
\text { (5) Strongly disagree }\end{array}$} \\
\hline & $\begin{array}{l}\text { 4) Perceived personal } \\
\text { obligation for behavior change }\end{array}$ & $\begin{array}{l}\text { No matter what other people do, due to my own } \\
\text { values and principles I feel obliged to reduce my car } \\
\text { use. }\end{array}$ & \\
\hline & $\begin{array}{l}\text { 5) Positive emotions for goal } \\
\text { intention }\end{array}$ & If I succeed in reducing my car use, I feel satisfied. & \\
\hline & $\begin{array}{l}\text { 6) Attitude toward potential } \\
\text { new behavior alternatives }\end{array}$ & $\begin{array}{l}\text { Currently, I still use the car often, but I am thinking } \\
\text { about reducing my car use. However, I am not sure } \\
\text { yet if and how I will reach this goal. }\end{array}$ & \\
\hline & 7) Intention to reduce car use & My intention to reduce my car use is ... & $\begin{array}{l}\text { (1) very strong. } \\
\text { (2) strong. } \\
\text { (3) neither strong nor weak. } \\
\text { (4) weak. } \\
\text { (5) very weak. }\end{array}$ \\
\hline $\begin{array}{l}\text { Behavioral } \\
\text { intention } \\
\text { (for actional } \\
\text { stage) }\end{array}$ & $\begin{array}{l}\text { Intention to implement new } \\
\text { behavior }\end{array}$ & $\begin{array}{l}\text { Currently, I still use the car often, but it is my fixed } \\
\text { goal to reduce my car use. I already know precisely } \\
\text { how to reach this goal, all I need to do is to realize } \\
\text { my plan. }\end{array}$ & $\begin{array}{l}\text { (1) Strongly agree } \\
\text { (2) Agree } \\
\text { (3) Neither agree nor disagree } \\
\text { (4) Disagree } \\
\text { (5) Strongly disagree }\end{array}$ \\
\hline $\begin{array}{l}\text { Implementation } \\
\text { intention } \\
\quad(\text { for } \\
\text { postactional } \\
\text { stage) }\end{array}$ & Maintenance & $\begin{array}{l}\text { Due to my interest in the topic daily mobility, I have } \\
\text { intentionally decided to use other means of } \\
\text { transportation instead of the car as often as possible. } \\
\text { Also in the following months, I will stick to my low } \\
\text { car use or rather reduce it even further. }\end{array}$ & $\begin{array}{l}\text { (1) Strongly agree } \\
\text { (2) Agree } \\
\text { (3) Neither agree nor disagree } \\
\text { (4) Disagree } \\
\text { (5) Strongly disagree }\end{array}$ \\
\hline
\end{tabular}




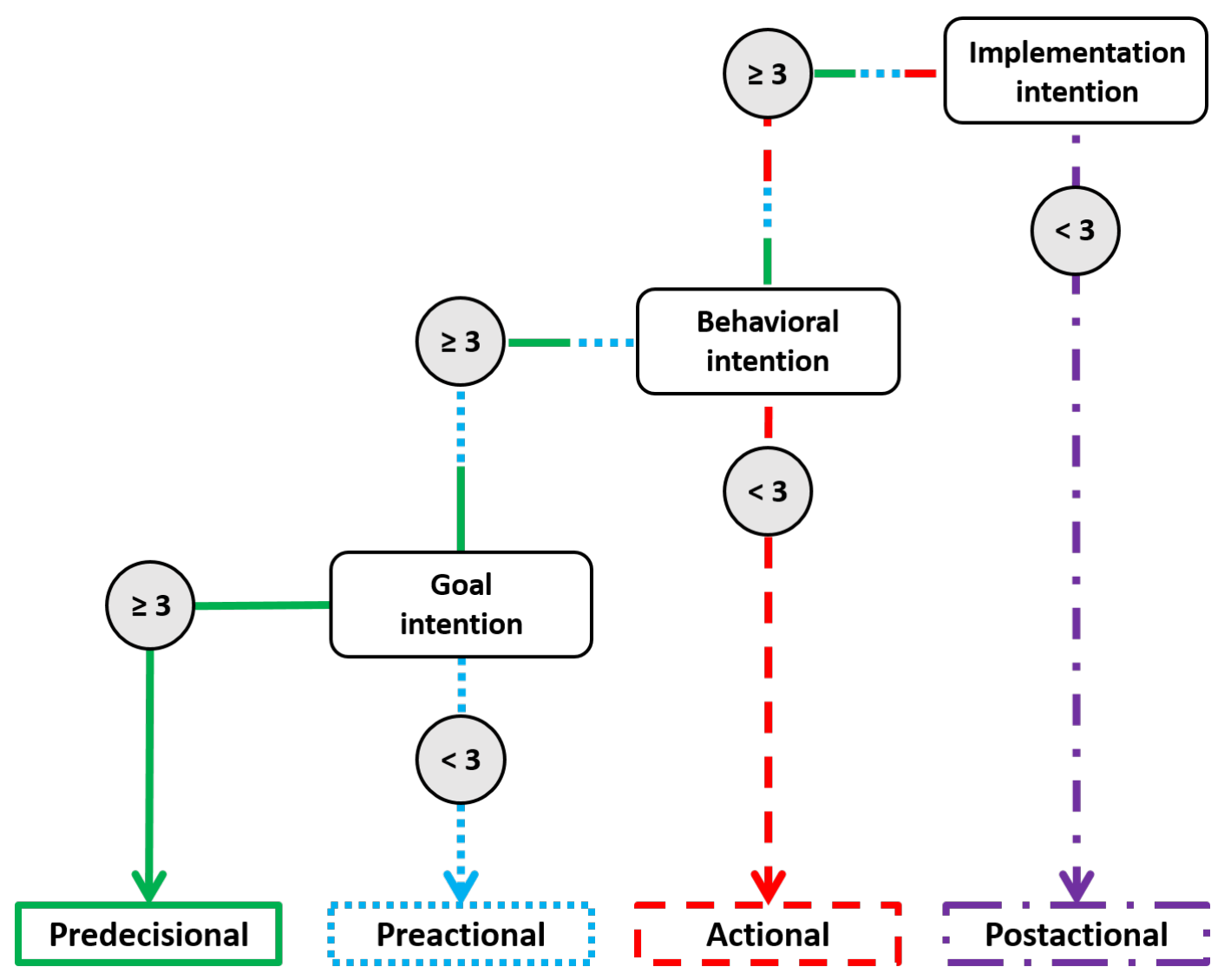

Figure 2: Flowchart for the categorization into the SSBC model. ' $<3$ ' and ' $\geq 3$ ' show the values of the answers to the indicator variables for the implementation intention and behavioral intention, and the mean values for the indicator variables for the goal intention (compare table 2).

The share of residents in the stages is not distributed evenly (table 3). Of the 627 residents that live in households with at least one private car, forty-four percent are in the predecisional stage, five percent belong to the preactional stage, two percent are in the actional stage, and nearly fifty percent form the postactional stage. As the amount of individuals in the preactional and actional stages are small compared to stages one and four, we merged them for further analyses.

As a plausibility check of the model, we compare the residents in the predecisional with the postactional stage (table 3). As anticipated from the SSBC's structure, from stage one to stage four we observe a thirty-two percentage points decrease in the frequency of car use and an increase in public transit and bike use, as well as higher walking rates. We performed a chi-square test of interdependence to examine the relation between each stage and the car-free households, and the respective residents' regular use of different means of transportation. We found that most relations in the predecisional and postactional stages as well as among the group of residents from car-free households are significant. Compared to the residents of car-free households, the residents in the postactional stage still have a higher car use, but at the same time also a higher bike use. The difference in car use between the households seems to be independent of the availability of cars because more than ninety percent of individuals in the predecisional stage and eighty-eight percent of individuals in the postactional stage have cars available anytime. In comparison, fourteen percent of individuals in households without cars have them available anytime. Similarly, the number of carsharing memberships is higher in the postactional than in the predecisional stage, but the highest among residents in a car-free household. Ultimately, our results seem to be consistent with the stage model theory. 
Table 3: Overview of mean mode use of the SSBC model's stages in comparison to car-free and any other household.

\begin{tabular}{|c|c|c|c|c|c|c|c|}
\hline & \multicolumn{5}{|c|}{ Individuals from households with $\geq 1$ car } & \multirow[b]{2}{*}{$\begin{array}{l}\text { Car-free } \\
\text { households } \\
(\mathrm{N}=400)\end{array}$} & \multirow[b]{2}{*}{$\begin{array}{c}\text { Total } \\
(\mathrm{N}=1027)\end{array}$} \\
\hline & $\begin{array}{c}\text { Predecisional } \\
\text { stage } \\
(\mathrm{N}=276)\end{array}$ & $\begin{array}{l}\text { Preactional } \\
\text { stage } \\
(\mathrm{N}=31)\end{array}$ & $\begin{array}{l}\text { Actional } \\
\text { stage } \\
(\mathrm{N}=10)\end{array}$ & $\begin{array}{l}\text { Postactional } \\
\text { stage } \\
(\mathrm{N}=310)\end{array}$ & $\begin{array}{l}\text { Total house- } \\
\text { holds with } \geq 1 \\
\text { car }(N=627)\end{array}$ & & \\
\hline \multicolumn{8}{|c|}{ Regular ${ }^{l}$ use by means of transportation } \\
\hline $\begin{array}{c}\text { Car } \\
\text { (as driver) }\end{array}$ & $0.87 * *$ & 0.77 & $(0.8)$ & $0.55^{* *}$ & 0.71 & $0.05^{* *}$ & 0.45 \\
\hline Public transit & $0.45^{* *}$ & 0.52 & $(0.7)$ & $0.68^{* *}$ & 0.57 & $0.82 * *$ & 0.67 \\
\hline Bicycle & $0.28^{* *}$ & 0.45 & $(0.4)$ & $0.62 * *$ & 0.46 & 0.50 & 0.47 \\
\hline Walking & 0.88 & 0.81 & $(0.8)$ & $0.92 *$ & 0.89 & 0.86 & 0.88 \\
\hline $\begin{array}{l}\text { Carsharing } \\
\text { membership }\end{array}$ & $0.09 *$ & 0.16 & $(0.1)$ & 0.14 & 0.12 & $0.27 * *$ & 0.18 \\
\hline
\end{tabular}

\section{The residents' view on parking policies}

\subsection{Acceptance of parking policy options}

Overall, the majority of residents agrees to most policy options and their items. However, we observe distinctions between the two policy types of restrictive and demand-oriented policies (table 4). The mean value for the restrictive policy of extended parking fees and parking restrictions is the lowest among all policy options. We discern a division of the six items of this policy: While there is no majority in favor of items regarding parking fees for all cars, most residents agree to limitations for sport utility vehicles (SUVs) to park on public parking space. Moreover, the mean value of the combined policy option of reuse of parking space for better livability is a bit higher. More than two-thirds are in favor of the reuse of parking space for pedestrian areas, wider sidewalks and more greenery, and the majority of residents only does not support the reuse of parking space for outside areas for retailers. Furthermore, we observe high acceptance rates for the demand-oriented policy option extension of bicycle infrastructure. The residents are in favor of all items related to this policy, especially of an extension of the bike lane network, with an exception for renting bike boxes. Likewise, many residents support the policy for improved sharing supply and mobility hubs. The residents do not endorse the items for more bike sharing supply, while the construction of mobility hubs in the neighborhood has the highest support. The policy option of neighborhood garages shows the second highest mean value, and a majority supports all three of its items. Finally, we observe the highest mean value for the policy option of improved public transit supply and its items. 
Table 4: Explanation of policy options and their descriptive statistics $(\mathrm{N}=1027)$.

\section{Policy options and indicators}

(1) I strongly disagree - (5) I strongly agree

\section{Restrictive parking policies}

(1) Extension of parking fees and parking restrictions $\mid \alpha=.803^{l}$

P1 I think there should be fees for all public parking space in Bornheim.

P2 I think the fees for parking in public space should be increased.

P3 I do not think it is the task of the city to provide free public parking space.

P4 I do not think parking space should be widened so that SUVs can easily fit in parking lots.

P5 I think one should pay more fees for parking SUVs than other cars.

P6 I advocate that SUVs should only be allowed on private parking space in Bornheim.

\begin{tabular}{|l|c|c|c|} 
& Mean & SD & $\begin{array}{c}\text { Percentage of } \\
\text { agreement }\end{array}$ \\
\hline & 2.8 & 1.020 & \\
\hline & 2.2 & 1.287 & $33 \%$ \\
\hline & 2.1 & 1.241 & $29 \%$ \\
\hline & 2.5 & 1.404 & $42 \%$ \\
\hline & 3.7 & 1.402 & $70 \%$ \\
\hline & 3.5 & 1.488 & $69 \%$ \\
\hline & 3.1 & 1.521 & $60 \%$ \\
\hline
\end{tabular}

\section{Combined parking policies}

\section{(2) Reuse of parking space for better livability $\mid \alpha=.881$}

R1 The Berger Straße should be transformed into a pedestrian and bicycle zone between the subway stations "Bornheim Mitte" and "Höhenstraße".

I would approve if public car parking space were transformed into ...

... wider sidewalks.

... greenery.

... garden areas.

... playgrounds.

.... seating.

... outside areas for restaurants and cafés.

... outside areas for retailers.

\begin{tabular}{|l|l|l|}
\hline 3.1 & 1.068 & \\
\hline 3.7 & 1.465 & $74 \%$ \\
\hline 3.2 & 1.354 & $70 \%$ \\
\hline 3.3 & 1.446 & $70 \%$ \\
\hline 2.9 & 1.454 & $54 \%$ \\
\hline 3.0 & 1.413 & $62 \%$ \\
\hline 3.0 & 1.410 & $61 \%$ \\
\hline 2.8 & 1.378 & $56 \%$ \\
\hline 2.3 & 1.187 & $37 \%$ \\
\hline
\end{tabular}

\section{Demand-oriented parking policies}

(3) Extension of bicycle infrastructure $\mid \alpha=.822$

B1 Weatherproof bicycle parking space should be installed in Bornheim.

B2 Bike boxes, small lockable garages for bicycles, should increasingly be installed in Bornheim.

B3 I would rent a parking lot in a bike box, if it would cost as much as a residential parking permit for a car (25€/year).

I would approve if public car parking space were transformed into ...

B4 ... bike lanes.

B5 $\ldots$ bicycle parking space.

B6 If car parking space were transformed, for me it would be important to also extend the bike lane network.

\begin{tabular}{|l|l|l|}
\hline 3.2 & 3.155 & \\
\hline 3.5 & 1.290 & $76 \%$ \\
\hline 3.1 & 1.330 & $62 \%$ \\
\hline 2.1 & 1.367 & $30 \%$ \\
\hline 3.4 & 1.371 & $73 \%$ \\
\hline 3.0 & 1.327 & $64 \%$ \\
\hline 3.8 & 1.285 & $83 \%$ \\
\hline
\end{tabular}

(4) Improved sharing supply and mobility hubs $\mid \alpha=.859$

S1 In my opinion, mobility hubs should be installed in Bornheim.

S2 I would use a mobility hub, if it were at a walkable distance from my home.

S3 If car parking space were transformed, for me it would be important to provide mobility hubs in central locations as well.

S4 I would approve if public car parking space were transformed into parking space for carsharing vehicles only.

If car parking space were transformed, for me it would be important to also provide ...

S5

... more carsharing supply.

S6 ... cheaper carsharing tariffs.

S7 $\quad$... more bike sharing supply.

(5) Neighborhood garages $\mid \alpha=.813$

NG1 In my opinion, more neighborhood garages should be built in Bornheim.

NG2 I would rent a parking lot in a neighborhood garage, if it were in walking distance of my home.

NG3 I am willing to pay an appropriate price for a parking space in a neighborhood garage.

\begin{tabular}{|l|l|l|}
\hline 3.1 & 0.975 & \\
\hline 3.5 & 1.191 & $80 \%$ \\
\hline 3.1 & 1.362 & $63 \%$ \\
\hline 3.1 & 1.192 & $71 \%$ \\
\hline 2.9 & 1.237 & $63 \%$ \\
\hline \multicolumn{2}{|l|}{} \\
\hline 3.1 & 1.320 & $65 \%$ \\
\hline 3.2 & 1.328 & $70 \%$ \\
\hline 3.5 & 1.204 & $48 \%$ \\
\hline 4.0 & 0.992 & \\
\hline 3.2 & 1.049 & $91 \%$ \\
\hline 3.2 & 1.396 & $67 \%$ \\
\hline 4.0 & 0.940 & $68 \%$ \\
\hline \multicolumn{2}{|c|}{} \\
\hline 3.7 & 1.232 & $82 \%$ \\
\hline 4.4 & 1.001 & $93 \%$ \\
\hline 3.8 & 1.407 & $78 \%$ \\
\hline
\end{tabular}

(6) Improved public transit supply $\mid \alpha=.622$

1.001

$78 \%$

PT1 ... increase the supply of public transit.

PT3 $\ldots$ provide fare-free public transit.

${ }^{1}$ For reliability analysis, we calculated Cronbach's alpha to assess the internal consistency of each scale. In the literature $\alpha \geq .7$ is discussed as acceptable (Schnell et al., 2013; Gliem and Gliem, 2003). Therefore, the coefficients are satisfactory except for the scale of improved public transit supply. 


\subsection{Bivariate analysis: Factors affecting the support of parking policy options}

To determine what factors influence the assessment of the policies, we differentiate between the personal characteristics of (i) car ownership in a household, (ii) private bicycle ownership, (iii) carsharing membership, (iv) regular usage rate of different means of transportation (private car, public transit, bicycle), (v) residential car parking, and (vi) classification into the SSBC.

By describing the assessments of the characteristics with semantic differentials, the data reveals similar support for the policy options to the aggregated results for all residents in the neighborhood (figure 3 ). The residents agree most to the policy options that consist of demand-oriented measures (extension of bicycle infrastructure, improved sharing supply and mobility hubs, neighborhood garages, and public transit supply), whereas the support for the policies, which include restrictive measures, are more diverse (extension of parking fees and parking restrictions, and reuse of parking space for better livability). For the latter as well as for the two policies regarding bicycle infrastructure and sharing services, we observe a difference in assessments between frequent car users and those who regularly use other means of transportation. Frequent car users show the lowest approval of these proposed policies, and residents from car-free households, carsharing members, and regular bike users are much more in favor of them.

Besides ownership and use, the residents' intention for behavior change towards reduced car use influences their agreement as well. The data also reveals a division between residents in different stages of the SSBC. While the residents in the predecisional stage show the lowest support of all residents for almost all policy options, the residents in the preactional/actional and postactional stages support the policies much more. Thus, the residents who still own private cars but already often use other means of transportation assess the policy options more similarly to residents who live in car-free households and regularly use a bike than the other residents from car-owning households in the predecisional stage. 


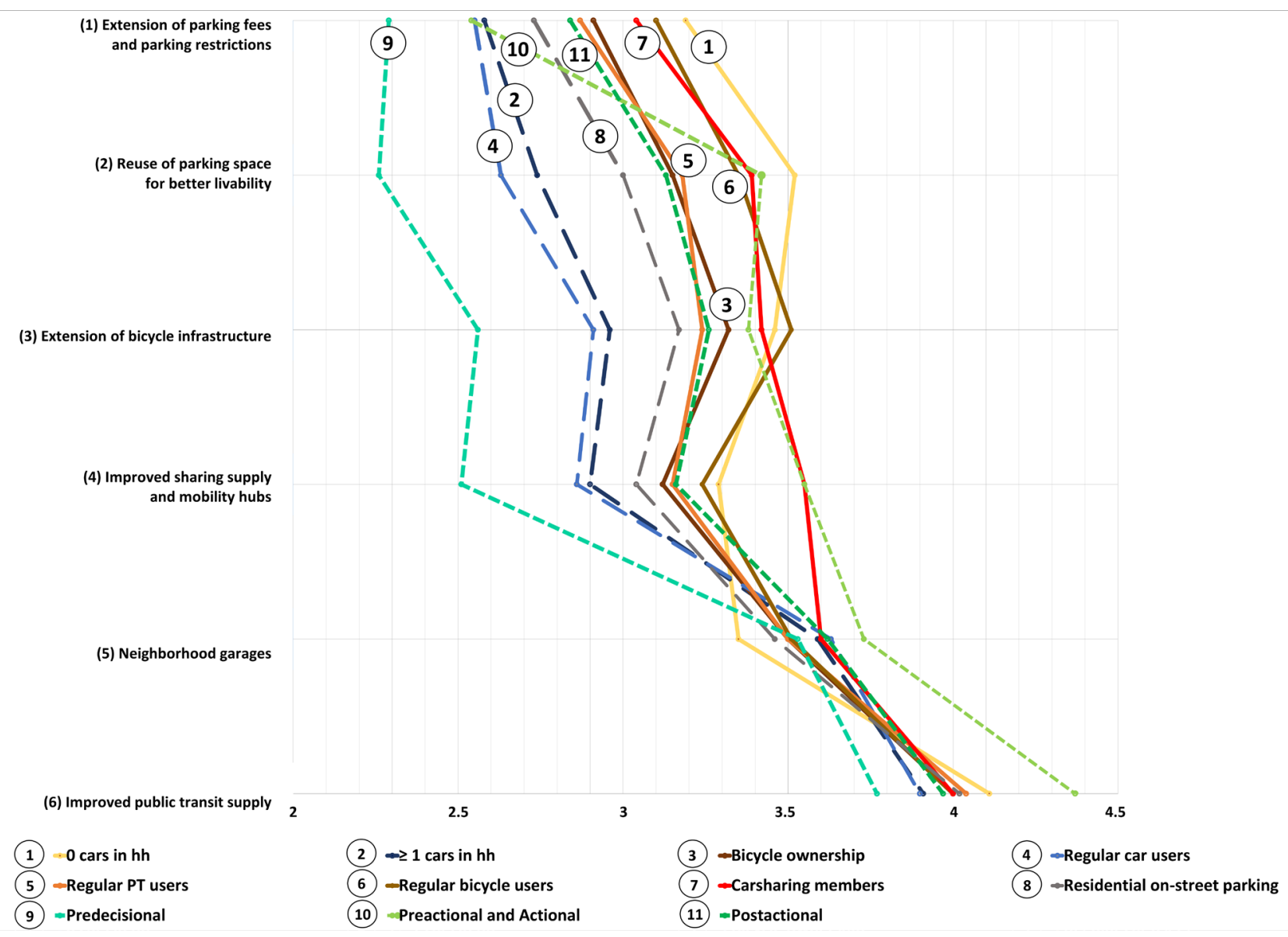

Figure 3: Residents agreements with policy options, (1) strongly disagree - (5) strongly agree.

Correlation analysis between the policy options and the residents' characteristics support these findings (table 5). On the one hand, the correlations reveal higher agreements in favor of the proposed policies from bike owners, carsharing members, regular public transit users, and regular bike users. Moreover, residents from car-free households assess the policies positively as well, except the policy for neighborhood garages. On the other hand, regular car drivers are not in favor of the policy options, with the exception of the measures around neighborhood garages. Furthermore, analyzing the different kinds of households with private cars in detail, the data reveals a separation between individuals in the predecisional and the postactional and preactional/actional stages. In addition, the type of residential parking space for the car owners seems to be especially important for their support of restrictive and combined policies because residents who park their cars on-street in public space are not in favor of an extension of parking fees and parking restrictions, and of reuse of parking space. 
Table 5: Correlations between policy options and resident groups.

\begin{tabular}{|c|c|c|c|c|c|c|}
\hline & $\begin{array}{l}\text { 1) Extension } \\
\text { of parking } \\
\text { fees and } \\
\text { parking } \\
\text { restrictions }\end{array}$ & $\begin{array}{l}\text { 2) Reuse } \\
\text { of parking } \\
\text { space for } \\
\text { better } \\
\text { livability }\end{array}$ & $\begin{array}{l}\text { 3) Extension } \\
\text { of bicycle } \\
\text { infrastructure }\end{array}$ & $\begin{array}{c}\text { 4) } \\
\text { Improved } \\
\text { sharing } \\
\text { supply and } \\
\text { mobility } \\
\text { hubs }\end{array}$ & $\begin{array}{c}5) \\
\text { Neighbor- } \\
\text { hood } \\
\text { garages }\end{array}$ & $\begin{array}{l}\text { 6) Improved } \\
\text { public } \\
\text { transit } \\
\text { supply }\end{array}$ \\
\hline \multicolumn{7}{|l|}{ Stages of $S S B C$} \\
\hline $\begin{array}{l}\text { Households with car ownership, } \\
\text { predecisional stage }\end{array}$ & $-.278 * *$ & $-.426 * *$ & $-.358 * *$ & $-.356 * *$ & -.051 & $-.122 * *$ \\
\hline $\begin{array}{l}\text { Households with car ownership, } \\
\text { preactional and actional stages }\end{array}$ & -.011 & $.165 * *$ & $.112 * *$ & $.179 * *$ & .039 & $.125 * *$ \\
\hline $\begin{array}{l}\text { Households with car ownership, } \\
\text { postactional stage }\end{array}$ & $.281 * *$ & $.341 * *$ & $.300 * *$ & $.265 * *$ & .032 & .059 \\
\hline Households without car ownership & $.293 * *$ & $.346^{* *}$ & $.250 * *$ & $.196 * *$ & $-.116 * *$ & $.104 * *$ \\
\hline \multicolumn{7}{|c|}{ Ownership/carsharing membership/residential parking } \\
\hline Private bicycle ownership & $.139 * *$ & $.136 * *$ & $.272 * *$ & $.111 * *$ & .010 & -.003 \\
\hline Private carsharing membership & $.101 * *$ & $.146^{* *}$ & $.125 * *$ & $.240 * *$ & .047 & .003 \\
\hline $\begin{array}{l}\text { Car owners with residential on-street } \\
\text { parking }\end{array}$ & $-.099 * *$ & $-.067 *$ & .012 & -.009 & -.035 & .038 \\
\hline \multicolumn{7}{|l|}{ Regularly used means of transportation } \\
\hline Car (as driver) & $-.240 * *$ & $-.363 * *$ & $-.229 * *$ & $-.178 * *$ & $.128 * *$ & $-.082 * *$ \\
\hline Public Transit & $.069 *$ & $.160 * *$ & $.128 * *$ & $.149 * *$ & .015 & $.073^{*}$ \\
\hline Bicycle & $.265^{* *}$ & $.255^{* *}$ & $.342 * *$ & $.188^{* *}$ & .011 & .011 \\
\hline
\end{tabular}

\subsection{Multivariate analysis: Factors that influence the assessment of parking policy options}

Finally, we performed multiple linear regression analyses (OLS) ${ }^{4}$ for each policy option to assess whether agreement rates differ depending on the classification into the SSBC, ownerships, carsharing membership, mode use, residential car parking, and, as control variables, socio-demographics (table 6). The results show that all models are significant at the one percent level. The regression models with the highest explained variances are reuse of parking space for better livability, extension of bicycle infrastructure, and extension of parking fees and parking restrictions. The models for neighborhood garages and improved public transit supply only have limited explained variances.

Being in the predecisional stage negatively affects the assessment of the combined and demand-oriented policies proposed: the reuse of parking space, the extension of bicycle infrastructure, the improved sharing supply and mobility hubs, neighborhood garages, and the improvement of the public transit supply. Being in the postactional stage, on the other hand, positively affects support for parking fees and parking restrictions. Simultaneously, living in a household that does not own private cars has a positive effect on the support for the extension of parking fees and restrictions, the reuse of parking space, and the extension of bicycle infrastructure. Moreover, the type of residential parking space negatively affects the assessment of policies regarding the reuse of parking space for better livability: Residents who park their cars on-street or use residential parking permits are not in favor of the proposed policies for the reuse of parking space.

\footnotetext{
${ }^{4}$ For the independent variables, we used the mean values of all items of each policy option category. We tested each model for multicollinearity. The models were adequate, with Pearsons' correlation coefficient $<0.8$, tolerance value $>0.1$, and variance inflation factor $<10$ (Backhaus et al., 2018; Cohen et al., 2003).
} 
Furthermore, owning a bike or having carsharing membership increases the probability of being in favor of policies related to bicycle infrastructure and sharing supply respectively. Besides this, regular bike use leads to being in favor of the restrictive and combined policies (parking fees and restrictions, and reuse of parking space), and two of the demand-oriented policies (extension of bicycle infrastructure, and improved sharing supply). Regular car use, however, leads to opposing changes in the reuse of parking space. In addition, regular public transit use also positively affects the residents' assessment of the extension of bicycle infrastructure and the improvement of sharing supply and mobility hubs.

Regarding socio-demographic factors, the data suggests that most are decisive only for extended parking fees and parking restrictions. The support for fees and restrictions increases with age and with a university degree, and a university degree also has a positive effect on the support for the policy option of improved sharing supply and mobility hubs. However, household income affects the assessments of four policies: the higher the income, the higher the support of residents for the extension of parking fees and parking restrictions, as well as for neighborhood garages. Simultaneously, the data suggests that a higher income leads to less support for the extension of bicycle infrastructure and improved public transit supply. Finally, gender seems to have no influence on the acceptance of any parking policy.

Table 6: Linear regression models (OLS) for policy options (beta coefficients).

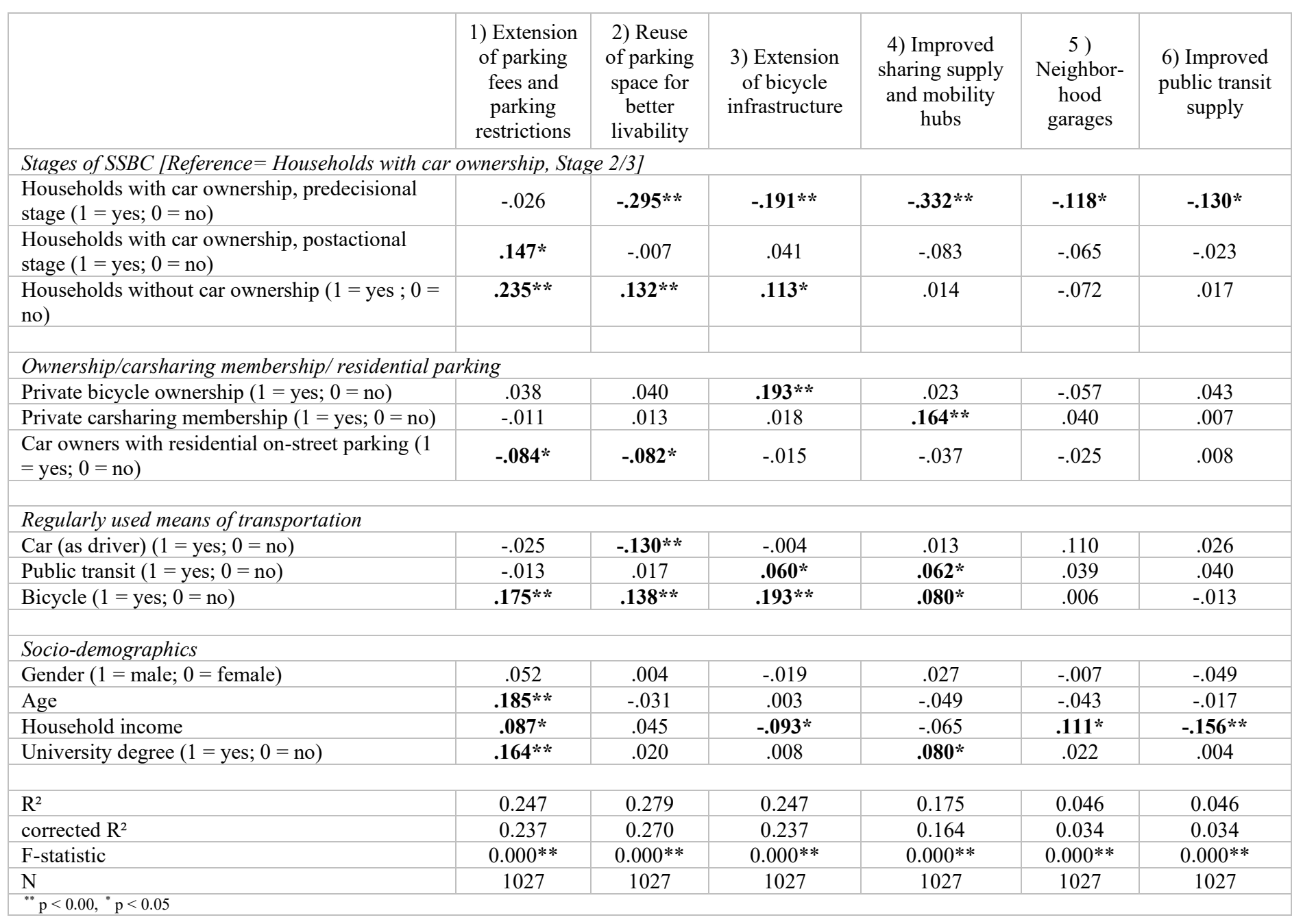




\section{Discussion}

Often, when a municipality plans to reuse on-street parking space for other purposes, it reports resistance from residents towards changes in urban parking space. Our results confirm and extend previous research on policy assessments with the focus on parking policies (e.g. Steg, 2003; Schade and Schlag, 2000; Jakobsson et al., 2000). Our data indicates that, surprisingly, the majority of residents support most policy options - both restrictive and demand-oriented items. However, detailed acceptance varies by the type of policy option and resident characteristics. We assume that the support for the demandoriented policies of neighborhood garages and improved public transit supply might be the highest because these policies do not constrain car use but are rather additional, complementary offers. This might be the same reason as to why the OLS models for these two policies only have limited explained variances. For the other four policy options, which are both restrictive, demand-oriented and combined instruments, we discovered high support as well, with the exception of policies concerning parking fees. In comparison, our analysis reveals the lowest support for financial-related items as part of restrictive measures. The literature suggests that residents need to view financial-related policies as being of benefit in order for a project to be successful among residents, and that municipalities need to ensure they communicate the benefits, even the individual ones for car drivers (Schaller, 2010; Jakobsson et al., 2000). Our survey did not include possible uses of the fees for parking and whether they would be utilized for city-wide improvements or changes at neighborhood level. Other studies suggest that the acceptance of parking fees could be increased if a municipality clearly communicated the purpose reusing parking fee revenues, for instance for more public transit supply or the extension of the pedestrian and bicycle network (Axhausen et al., 2015; Ottosson et al., 2013).

Furthermore, the classification of residents who live in households with at least one private car into the stages of the SSBC regarding a reduction in car use reveals differences within the households that own cars and their support for the parking policy options. Thus, as an implication for municipalities and policy makers, the residents in the postactional stage are an important group because they intend to change their personal behavior towards reduced car use. They already regularly use more environmentally friendly means of transportation than the private car and are more similar to residents of car-free households than to residents in the predecisional stage. They do not seem to perceive unfairness or an infringement of freedom from the proposed policies even though they rely on car parking infrastructure (Kim et al., 2013; Schaller, 2010). Consequently, they might be receptive to campaigns aimed at giving up private cars. Hence, the results show that there is not 'one solution fits all' but rather different strategies for addressing each household group, for instance, which incentives might work best for each. So, from the perspective of practitioners and politicians the communication strategy of administrations towards car-owning households and the type of intervention need to vary depending on the kind of household and its intention to change behavior towards less car use (Bamberg, 2013).

In addition, the type of parking space at home (on-street or reserved off-street) only affects the acceptance of policies regarding the extension of parking fees and parking restrictions, and the reuse of parking space for other purposes. To the best of our knowledge, this study is the first to use residential parking space for the residents' assessment of parking policies. Moreover, sociodemographic variables do not primarily seem to influence the support of the proposed parking policies, except for obtaining a university degree and household income. Other studies discovered that people with low income are less willing to accept increased transport pricing (Jakobsson et al., 2000). In our analysis, a low income seems to affect financial-related policies negatively as well, and instead positively affects support for the extension of bicycle infrastructure and improved public transit supply. 
Finally, studies concerning the proposed introduction of road pricing have shown that a small group of people are capable of blocking a proposal for a project if they perceive it to be unfair and an infringement of freedom (Kim et al., 2013; Schaller, 2010). Our analysis also suggests that it is a minority and not the majority that is reluctant towards changes in parking space. This is partly due to the fact that approximately fifty percent of the residents from households with cars are not regular car users. To prevent resistance from resident groups, it is essential to combine restrictive and demand-oriented instruments because of their interdependence (Bamberg et al., 2011; Steg, 2003). As indicated for financial-related items, earlier studies revealed that acceptance among residents could be increased if, along with the implementation, the municipality communicates the positive aspects of the policies: for instance, the improvement of public goods or environmental aspects (e.g. Grisolía et al., 2015; Kim et al., 2013). Our data reveals that the majority of the residents (including individuals from car-owning households) supports the reuse of on-street parking space as long as the parking space is not simply blocked, but opened for other purposes and for other users of public space. Thus, the analysis shows that not only the loss of something (e.g. parking space), but also the gain of something else (e.g. greenery) affects assessments. Politicians and planners should use the positive aspects of "parking space loss", i.e. the gain of space for pedestrians and bicyclists, and for livability in the neighborhood. Thus, in contrast to the introduction of a city toll, the positive aspects from the transformation of parking space (e.g. wider sidewalks) are directly observable, and need to be clearly communicated. Still, even after the implementation of a congestion charging system in, for instance, Stockholm, the initially low approval rates for the toll increased after its introduction (Eliasson et al., 2009). This indicates that initial protests from residents against parking management might develop into consent as well.

Ultimately, the majority of the residents perceives the neighborhood as walkable because almost ninety percent of the residents regularly walk. Thus, the possible peculiarity of the neighborhood with such high walkability and support for parking policies should be kept in mind when examining the results. Yet, when comparing it to other urban neighborhoods, we assume that the support for the policies discussed is similar in other densely populated inner-city areas with a relatively high share of car-free households (e.g. amounting to forty percent in the German metropolitan core areas; infas and DLR, 2019). In addition, we only distributed the survey among residents and did not include the local retailers. In future studies, it could yield more insight if the retailers were asked for their assessment as well, especially as the survey included questions regarding the reuse of parking space in the main shopping street of the neighborhood.

Our analysis revealed an imbalance in the distribution of residents from car-owning households into the stages of the SSBC. This may be a shortcoming of the model or it may reflect that behavior change is an exceptional case and behavior usually follows a set of routines. Therefore, focusing on using the SSBC with residents who have just recently moved may lead to different results because a relocation as a key event can weaken routines (Müggenburg et al, 2015). Furthermore, we based the statements for the classification into the SSBC on Bamberg's (2012) proposals. We added further constructs - again based on Bamberg (2012) - for indicating the transition from the predecisional into the preactional stage (goal intention) because the proposals included more than one statement for one construct. Retrospectively, however, we realized it might be inefficient to have an unbalanced number of constructs for the transitions. Other approaches for using the SSBC and determining the stage classification are to provide only one statement for each stage between which the participants choose the one that fits them best (e.g. Olsson et al., 2018; Nkurunziza et al., 2012) or merging both reduced car use and increased bicycle use into one model (Blitz et al., 2020; Keller et al., 2019). 


\section{Summary}

Residential parking in urban neighborhoods influences the car ownership and car use of households. Thus, parking is a main factor in managing urban mobility. As the success of parking management depends on the residents' acceptance of parking policies, the aim of this paper was to assess to what extent residents in a dense urban neighborhood support restrictive and demand-oriented on-street parking policy options. We therefore conducted a household survey in the centrally located neighborhood of Frankfurt-Bornheim.

First, our analysis reveals high approval rates for all policy options from different residents in the neighborhood. The socio-demographic factors seem to play a minor role in their assessments. Second, while we observe support for the policy options of neighborhood garages and improved public transit supply throughout, the results reveal more varied opinions about the extension of parking fees and parking restrictions, the reuse of parking space for better livability, the extension of bike infrastructure, and improved sharing supply and mobility hubs. The data indicates that the different assessments might be a result of the type of policy options, i.e. whether they include restrictive items and whether new offers are based on the reuse of parking space. Third, we discover diverging opinions about the policy options from residents who live in households with cars and those from car-free households. However, fourth, as expected from the SSBC, residents of households with private cars who are in the postactional stage of the behavior change model show similar assessment patterns to residents living in car-free households. Therefore, seventy percent of all residents in the data set support both demand-oriented policies and restrictive policy options. Thus, not only the ownership and use of means of transportation but, also the intention towards personal behavior change has an influence on the support for the policy options. Fifth, our analysis identifies different kinds of households with private cars regarding their intention for behavior change. The residents in the postactional stage are an important target group for cities because these individuals have the highest probability benefitting from municipalities' incentives to give up their private cars. Additionally, municipalities need more variety of communication strategies and types of transportation demand management to be able to address the targeted group effectively. Finally, the positive aspects from the transformation of parking space could be used. The analysis illustrates that residents in the postactional stage, who still need parking space, are in favor of the modification if the reuse provides new space for other purposes and users of public space.

In conclusion, it would be of interest not only to enquire as to the reasons that residents live in car-free households, but also to investigate the reasons why other residents own cars, and under what conditions it would be worthwhile for them to become less car dependent. This data would be helpful to gain a deeper understanding of the motives for car ownership in centrally located neighborhoods with alternatives to the private car like public transit and carsharing. If we understood this rationale better, we might be able to stimulate behavior change towards reduced car ownership and associated parking space use even more, and improve the acceptance of parking management. Finally, more design options, than the ones used in this study are possible to make use of on-street parking space, for instance, parklets and pop-up uses (Rose, 2019), and one could reproduce the study not only in urban, dense neighborhood but also in low-density residential neighborhoods or in small towns. Thigpen and Volker (2017) and Schlossberg and Amos (2015) point out that since on-street parking space in these neighborhoods is often oversupplied and underused there is room for reuse opportunities here as well, like space for rainwater capture, urban farming or accessory dwelling units. 


\section{References}

Antonson, H., Hrelja, R., Henriksson, P., 2017. People and parking requirements: Residential attitudes and day-to-day consequences of a land use policy shift towards sustainable mobility. Land Use Policy 62, 213-222. http://dx.doi.org/10.1016/j.landusepol.2016.12.022.

Axhausen, K., Chikaraishi, M., Seya, H., 2015. Parking: Learning from Japan. Arbeitsberichte Verkehrs- und Raumplanung: Vol. 1095. Zurich: Eidgenössische Technische Hochschule Zürich.

Backhaus, K., Erichson, B., Plinke, W., Weiber, R., 2018. Multivariate Analysemethoden. Eine anwendungsorientierte Einführung. Berlin, Heidelberg: Springer Gabler.

Banister, D., 2005. Unsustainable transport - City transport in the new century. Abingdon: Routledge.

Bamberg, S., 2013. Applying the stage model of self-regulated behavioral change in a car use reduction intervention. J. of Environ. Psychol. 33, 68-57.

http://dx.doi.org/10.1016/j.jenvp.2012.10.001.

Bamberg, S., 2012. Wie funktioniert Verhaltensveränderung? Das MAX-Selbstregulationsmodell. In: Stiewe, M., Reutter, M., (Eds), Mobilitätsmanagement: Wissenschaftliche Grundlagen und Wirkungen in der Praxis. Essen: Klartext Verlag, pp. 76-101.

Bamberg, S., Fujii, S., Friman, M., Gärling, T., 2011. Behavior theory and soft transport policy measures. Transp. Policy 18, 228-235. https://doi.org/10.1016/j.tranpol.2010.08.006.

Bamberg, S., Haller, J., Heipp, G., Nallinger, S., 2008. Multimodales Marketing für Münchener Neubürger: Entwicklung, Evaluation, Ausblick. Int. Verk.-wes. 60(3), 73-76.

Binson, D., Canchola, J. A., Catania, J. A., 2000. Random selection in a national telephone survey: A comparison of the Kish, Next-Birthday, and Last-Birthday method. J. of Off. Statistics 16(1), 53-59.

Blitz, A., Busch-Geertsema, A., Lanzendorf, M., 2020. More cycling, less driving? Findings of a cycle street intervention study in the Rhine-Main metropolitan region. Sustain. 12(805), 1-25.

https://doi.org/10.3390/su12030805 (submitted for publication).

Buehler, R., Pucher, J., Gerike, R., Götschi, T., 2016. Reducing car dependence in the heart of Europe: lessons from Germany, Austrian, and Switzerland. Transp. Rev. 37(1), 4-28.

http://dx.doi.org/10.1080/01441647.2016.1177799.

Chang, W. C., 2014. Whose parking space is it? Managing residential parking in the context of urban growth: Case study of Cambridge, MA. Master thesis, MIT.

Chester, M., Horvath, A., Madanat, S., 2010. Parking infrastructure: energy, emissions, and automobile life-cycle environmental accounting. Environ. Res. Lett. 5(3) 1-8.

https://doi.org/10.1088/1748-9326/5/3/034001.

Christiansen, P., Fearnley, N., Usterud, J., Skollerud, K., 2017. Household parking facilities:

Relationship to travel behavior and car ownership. Transp. Res. Proced. 25, 4185-4195.

https://doi.org/10.1016/j.trpro.2017.05.366.

City of Frankfurt, Bürgeramt Statistik und Wahlen, 2019. Materialien zur Stadtbeobachtung, Heft 28. https://frankfurt.de/service-und-rathaus/zahlen-daten-fakten (accessed February 21, 2020).

Cohen, J., Cohen, P., West, S. G., Aiken, L. S., 2003. Applied multiple regression/correlation analysis for the behavioral sciences. Mahwah, NJ: Erlbaum. 
DiClemente, C. C., Prochaska, J. O., 1982. Self-change and therapy change of smoking behavior: A comparison of processes of change in cessation and maintenance. Addict. Behav. 7, 133-142.

Diekmann, A., 2017. Empirische Sozialforschung - Grundlagen, Methoden, Anwendungen. Reinbek bei Hamburg: Rowohlt.

Eliasson, J., Hultkrantz, L., Nerhagen, L., Smidfelt Rosqvist, L., 2009. The Stockholm congestion charging trial 2006: Overview of effects. Transp. Res. Part A 43, 240-250.

https://doi.org/10.1016/j.tra.2008.09.007.

Fuller, W. A., 2009. Sampling statistics. Hoboken: John Wiley \& Sons.

Gehl, J., 2010. Cities for people. Washington, DC: Island Press.

Gliem, J. A., Gliem, R. R., 2003. Calculating, interpreting, and reporting Cronbach's Alpha reliability coefficient for Likert-type scales. Midwest Research-to-Practice Conference in Adult, Continuing, and Community Education. Columbus, OH, 8-10 October.

Grisolía, J. M., López, F., de Dios Ortúzar, J., 2015. Increasing the acceptability of a congestion charging scheme. Transp. Policy 39, 37-47. http://dx.doi.org/10.1016/j.tranpol.2015.01.003.

Groth, S. 2016. Nach dem Auto Multimodalität? - Materielle und mentale Multioptionalität als individuelle Voraussetzungen für multimodales Verhalten. PhD Thesis, Goethe-University Frankfurt am Main.

Guo, Z., 2013. Does residential parking supply affect household car ownership? The case of New York City. J. of Transp. Geogr. 26, 18-28. http://dx.doi.org/10.1016/j.jtrangeo.2012.08.006.

Harms, S., Probst, J., 2008. Nachhaltiger Stadtverkehr - Beeinflussung des Konsumentenverhaltens durch push- und pull-Maßnahmen. Umweltpsychol. 12(1), 80-100.

Infas (Institut für angewandte Sozialwissenschaft), DLR (Deutsches Zentrum für Luft- und Raumfahrt), 2019. Mobilität in Deutschland - Kurzreport. http://www.mobilitaet-indeutschland.de/pdf/infas_Mobilitaet_in_Deutschland_2017_Kurzreport.pdf (accessed October 14, 2019).

Jakobsson, C., Fujii, S., Gärling, T., 2000. Determinants of private car users' acceptance of road pricing. Transp. Policy 7, 153-158. https://doi.org/10.1016/S0967-070X(00)00005-6.

Johansson, F., Henriksson, G., Envall, P., 2019. Moving to private-car-restricted and mobility-served neighborhoods: The unspectacular workings of a progressive mobility plan. Sust. 11(6208), 1-19. https://doi.org/10.3390/su11226208.

Kaufmann-Hayoz, R., Bättig, C., Bruppacher, S., Defila, R., Di Gulio, A., Flury-Kleubler, P., Friedrich, U., Garbely, M., Gutscher, H., Jäggi, C., Jegen, M., Mosler, H.-J., Müller, A., North, N., Ulli-Beer, S., Wichtermann, J., 2001. A Typology of Tools for Building Sustainability Strategies. In: Kaufmann-Hayoz, R., Gutscher, H., (Eds), Changing things - moving people. Strategies for promoting sustainable development at the local level. Basel: Birkhäuser Verlag, pp. 33-107.

Kromrey, H., 2002. Empirische Sozialforschung: Modelle und Methoden der standardisierten Datenerhebung und Datenauswertung. Opladen: Leske und Budrich. 
Keller, A., Eisen, C., Hanss, D., 2019. Lessons learned from applications of the Stage Model of SelfRegulated Behavioral Change: A review. Front. in Psychol. 10(1091), 1-6.

https://doi.org/10.3389/fpsyg.2019.01091.

Kim, K., Schmöcker, J., Noland, R. B., 2013. Attitudes towards road pricing and environmental taxation among US and UK students. Transp. Res. Part A 48, 50-62.

http://dx.doi.org/10.1016/j.tra.2012.10.005.

Kirschner, F., 2019. Methodenbericht zur Haushaltsbefragung "Quartiersentwicklung und Mobilität in Bornheim”. Arbeitspapiere zur Mobilitätsforschung Nr. 20. Frankfurt am Main: Goethe University. http://publikationen.ub.uni-frankfurt.de/frontdoor/index/index/docId/46487 (accessed September 10, 2019).

Kirschner, F., Lanzendorf, M., 2019. Parking management for promoting sustainable transport in urban neighbourhoods. A review of existing policies and challenges from a German perspective. Transp. Rev. https://doi.org/10.1080/01441647.2019.1666929.

Loukopoulos, P., 2007. A classification of travel demand management measures. In: Gärling, T., Steg, L., (Eds), Threats from car traffic to the quality of urban life. Oxford: Elsevier, pp. 275-292.

Litman, T., 2016. Parking Management: Strategies, Evaluation and Planning. Victoria, BC: Victoria Transport Policy Institute.

Marsden, G., 2014. Parking policy. In: Ison, S., Mulley, C., (Eds), Parking: Issues and policies. Bingley: Emerald Group, pp. 11-32.

Mattioli, G., Anable, J., Goodwin, P., 2019. Analysis of NTS data. Commission on Travel Demand Shared Mobility Inquiry: Evidence Session 3. https://www.creds.ac.uk/commission-on-travel-demandshared-mobility-inquiry-evidence-session-3/ (accessed September 18, 2019).

Mingardo, G., Van Wee, B., Rye, T., 2015. Urban parking policy in Europe: A conceptualization of past and possible future trends. Transp. Res. Part A 74, 268-281.

http://dx.doi.org/10.1016/j.tra.2015.02.005.

Müggenburg, H., Busch-Geertsema, A., Lanzendorf, M., 2015. Mobility biographies: A review of achievements and challenges of the mobility biographies approaches and a framework for further research. J. of. Transp. Geog. 46, 151-163. http://dx.doi.org/10.1016/j.jtrangeo.2015.06.004.

Nehrke, G., Loose, W., 2018. Nutzer und Mobilitätsverhalten in verschiedenen Carsharing-Varianten. Berlin: Bundesverband CarSharing.

Newman, P., Kenworthy, J., 2015. The end of automobile dependence: How cities are moving beyond car-based planning. Washington, DC: Island Press.

Nkurunziza, A., Zuidgeest, M., Brussel, M., Van Maarseveen, M., 2012. Examining the potential for modal change: Motivators and barriers for bicycle commuting in Dar-es-Salaam. Transp. Policy 24, 249-259. http://dx.doi.org/10.1016/j.tranpol.2012.09.002.

Notz, J. N., 2017. Die Privatisierung öffentlichen Raums durch parkende Kfz: Von der Tragödie einer Allmende - über Ursache, Wirkung und Legitimation einer gemeinwohlschädigenden Regulierungspraxis. IVP-Discussion Paper 2017(1). Berlin: Technische Universität Berlin.

Olsson, L., Huck, J., Friman, M., 2018. Intention for car use reduction: Applying the stage-based model. Int. J. of Env. Res. and Public Health 15(216), 1-15. https://doi.org/10.3390/ijerph15020216. 
Prochaska, J. O., DiClemente, C. C., 1983. Stages and processes of self-change of smoking: Toward an integrative model of change. J. of Consult. and Clin. Psychol. 51(3), 390-395.

https://psycnet.apa.org/doi/10.1037/0022-006X.51.3.390.

Rose, S., 2019. Fast cars and empty spaces: Identifying barriers to urban vitality on highway-adjacent corridors in Baltimore, Maryland. Master thesis, Georgetown University.

Rye, T., Koglin, T., 2014. Parking management. In: Ison, S., Mulley, C., (Eds), Parking: Issues and policies. Bingley: Emerald Group, pp. 157-184.

Schade, J., Schlag, B., 2003. Acceptability of urban transport pricing strategies. Transportation Research Part F 6, 45-61. https://doi.org/10.1016/S1369-8478(02)00046-3.

Schaller, B., 2010. New York City's congestion pricing experience and implications for road pricing acceptance in the United States. Transp. Policy 17, 266-273.

https://doi.org/10.1016/j.tranpol.2010.01.013.

Schlossberg, M., Amos, D., 2015. Rethinking residential on-street parking. In: Talen, E. (Ed), Retrofitting sprawl: Addressing seventy years of failed urban form. Athens, GA: The University of Georgia Press, pp. 181-198.

Schmöcker, J.-D., Pettersson, P., Fujii, S., 2012. Comparative analysis of proximal and distal determinants for the acceptance of coercive charging policies in the UK and Japan. Int. J. of Sustain. Transp. 6, 156-173. https://doi.org/10.1080/15568318.2011.570856.

Schnell, R., Hill, P. B., Esser, E., 2013. Methoden der empirischen Sozialforschung. Munich: Oldenbourg Wissenschaftsverlag.

Schreier, H., Becker, U., Heller, J., 2015. Evaluation CarSharing (EVA-CS): Landeshauptstadt München. Berlin: team red Deutschland.

Scott, J., Marshall, G., 2015. A supplementary dictionary of social research methods. Oxford: Oxford University Press.

Shoup, D. C., 2005. The high cost of free parking. Chicago: Planners Press, American Planning Association.

Steg, L., 2003. Factor influencing the acceptability and effectiveness of transport pricing. In: Schade, J., Schlag, B., (Eds), Acceptability of transport pricing strategies. Oxford: Elsevier, pp. 187-202.

Spieß, M., 2010. Der Umgang mit fehlenden Werten. In: Wolf, C., Best, H., (Eds), Handbuch der sozialwissenschaftlichen Datenanalyse. Wiesbaden: VS Verlag für Sozialwissenschaften, pp. 117-142.

Thigpen, C. G., Volker, J. M. B., 2017. Repurposing the paving: The case of surplus residential parking in Davis, CA. Cities 70, 111-121.

Weinberger, R., Seaman, M., Johnson, C., 2009. Residential off-street parking impacts on car ownership, vehicle miles traveled, and related carbon emissions: New York City case study. Transp. Res. Rec. 2118, 24-30. https://doi.org/10.3141/2118-04. 